\title{
EIJEST
}

\section{CHARACTERISTICS OF FREE FLOW BELOW SLUICE GATE BELOW RADIAL STILLING BASIN WITH NEGATIVE STEP*}

\author{
Amany A. Habib** \\ Dept. of Water \& Water Structures Engineering, \\ Faculty of Engineering, Zagazig University, Zagazig, Egypt
}

\begin{abstract}
Steps may be constructed in stilling basins based on land topography and design requirements for the purpose of increasing the energy dissipation and reducing the length of hydraulic jump. This paper aims to investigate the effect of a negative step located in radial stilling basin on the discharge of a free flow gate conditions. The effect of both step height and position downstream the gate is investigated experimentally by analyzing large series of experimental data. The data are collected using a laboratory flume of relatively large dimensions $(30 \mathrm{~cm}$ wide, $45 \mathrm{~cm}$ depth, and $15 \mathrm{~m}$ long). A diverging channel reach with fixed length and constant divergence angle is used. The effects of Different relative height and relative positions of negative step on the coefficient of discharge and the relative energy loss through the gate are also investigated experimentally. The dimensional analysis was used to correlate the discharge coefficient to the other relevant flow and step parameters. It is found that the presence of negative step down stream the gate in a radial stilling basin has a remarkable negative effect on the discharge coefficient and remarkable positive one on the energy loss through the gate. Dimensionless general equations in terms of the flow and step parameters for computing the coefficient of discharge of the sluice gate is developed using the multiple regression analysis. The obtained predictions of the discharge coefficient using the developed equations are compared to the experimental data. The developed equations proved good reliability and high accuracy.
\end{abstract}

KEY WORDS: sluice gate, stilling basin, negative step, discharge coefficient, energy loss

\section{ARACTERISTIQUES DE L'ECOULEMENT LIBRE EN DESSOUS DE VANNES MURALES DESSOUS AVEC BASSIN D'AMORTISSEMENT RADIAL PAS NEGATIF}

\section{RÉSUMÉ}

Cette mesure du papier dans quelle mesure, le Génie Industriel (IE) des techniques, sont appliquées dans les petites et moyennes entreprises (PME) de gérer la productivité, de diagnostiquer les raisons de facilité d'utilisation de techniques à faible IE. Il décrit un grand nombre de définitions pour les PME et leur rôle important dans l'économie égyptienne. Ainsi, un questionnaire a été conçu pour établir la base factuelle sur l'utilisation de techniques d'IE dans les PME régionales en Egypte. Les résultats du sondage ont été analysés pour diagnostiquer le pour cent de l'applicabilité de ces techniques et leur relation avec le type d'industrie et le volume de l'entreprise. Le mix d'activités a été choisi pour embrasser les secteurs de la fabrication et le commerce séparément et pour déterminer si des groupes d'affaires différents ont des approches différentes pour l'utilisation des meilleures techniques IE pratique. Le questionnaire avait plusieurs sections avec des questions choisies afin d'examiner l'utilité des techniques d'IE que chaque question a plusieurs choix et le gestionnaire responsable peut choisir un de ces choix. Le questionnaire n'a pas été le seul moyen de recueillir des données, mais aussi l'observation directe pendant près de deux jours dans chaque entreprise industrielle et quelques heures pour les entreprises commerciales dont les propriétaires acceptent de partager dans le questionnaire. Une feuille Excel a été conçu pour l'analyse des données recueillies et d'obtenir les tableaux représentés. Enfin, les résultats du questionnaire ont été analysés afin de déterminer les principales causes de difficulté d'appliquer les techniques d'IE dans les PME.

MOTS CLÉS: techniques de IE, petites et moyennes entreprises, la prévision de la demande, la planification des installations, le transport, l'étude la méthode, la mesure du travail, planification de la production et le contrôle, contrôle qualité, et de la maintenance...

\footnotetext{
* Received: 26/6/2011, Accepted: 17/7/2011 (Original Paper)

** Contact Author (amanyhabib89@yahoo.com)
} 


\section{INTRODUCTION}

Gates are used to control and regulate the discharge of flow at the entrance of irrigation canals. The gates disturb the flow and create non-uniform flow conditions upstream and downstream of the gate. The flow from these gates may be free or submerged depending on the tail water depth. The flow characteristics beneath the gates have been studied extensively theoretically and experimentally by many researchers, e.g., Henery [10], Henderson [9], Rajratnam and Subramanya [21], Swamee [25], Ohatsu and Yasuda [20], Rajratnam [22]. Many others investigated the effect of constructing sills under sluice gates. Some of these studies dealt with the free flow, Ranja Raju and Visavadia [23], Ranga Raju [24], Abdelaal [1], Negm et al. [14, 17]. While other dealt with the submerged flow, El-Saiad et al. [5, 6], Negm and El-Saiad [15] and Negm [16]. Other studies dealt with the effect of gate or sill configuration on the flow below the gate, (1995). Characteristics of flow below gates without sill in non-prismatic channels were studies by Negm et al. [18, 19] for free flow and by Ibrahim [11] for submerged flow. On the other hand, the hydraulic jump characteristics in nonprismatic channels were investigated by many investigators, Arbhabhirama and Abella [4],
Khalifa and Mcorquodale [12], France [7], and Abdel-Aal [2, 3]. It was found that the radial basin was more effective in dissipating the energy than the rectangular one. Therefore, it is preferred to use the radial basins to ensure more safety of the hydraulic structures against failure and to be more economic. This study investigates the discharge characteristics of gates upstream of radial diverging stilling basin with the presence of a vertical negative step for free flow conditions to provide more information about the effect of the step parameters $\mathrm{Z} / \mathrm{G}$ and $\mathrm{L} / \mathrm{G}$ on flow below free sluice gate. Using multiple regression analysis dimensionless equations are developed for predicting the coefficient of discharge for free sluice gate.

\section{THEORETICAL BACKGROUND}

Fig. (1) shows a typical definition sketch for free flow below sluice gate in radial stilling basin with negative step at different positions. Applying the principles of dimensional analysis, the following functional relationship for coefficient of discharge of the free gate, $\mathrm{C}_{\mathrm{d}}$, can be proved as:

$$
\mathrm{C}_{\mathrm{d}}=f\left(\mathrm{~L} / \mathrm{G}, \mathrm{Z} / \mathrm{G}, \mathrm{H} / \mathrm{G}, \mathrm{F}_{\mathrm{G}}\right)
$$

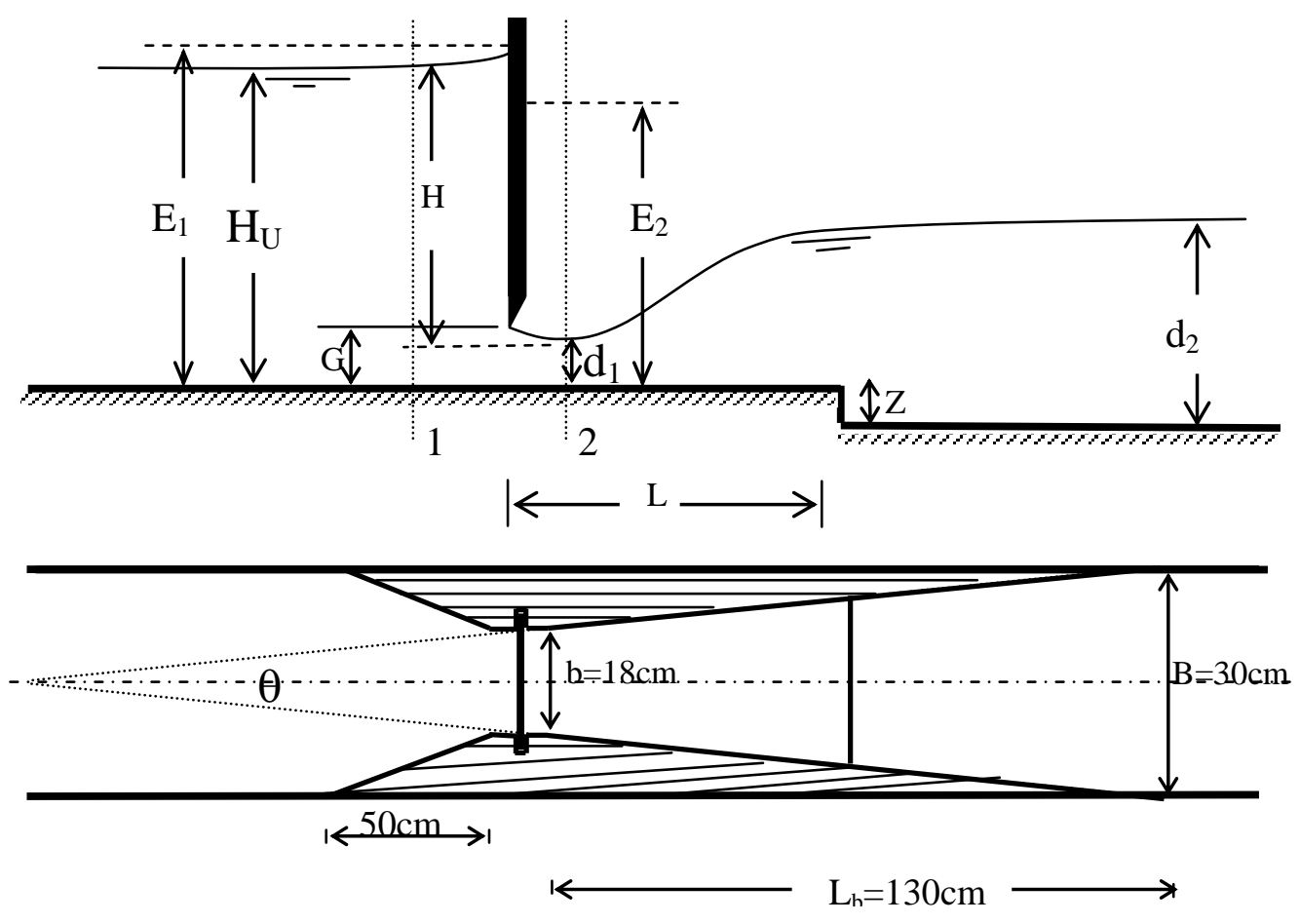

Fig. (1): Definition sketch for free flow below gate US horizontal radial stilling basin with negative step 
And the discharge coefficient $\left(\mathrm{C}_{\mathrm{d}}\right)$ of sluice gate for free flow (Fig. 1) is computed based on the following equation:

$$
\mathrm{C}_{\mathrm{d}}=\frac{\mathrm{Q}}{\mathrm{Gb} \sqrt{2 \mathrm{gH}}}
$$

Where $C_{d}$ is the discharge coefficient of sluice gate, $\mathrm{G}$ is the gate opening height, $\mathrm{H}$ is the upstream water depth over vena-contracta, $b$ is the width of the flume at the gate location, $\mathrm{Q}$ is the discharge passing through the flume, $\mathrm{g}$ is the acceleration due to gravity, $\mathrm{Z} / \mathrm{G}$ relative height of step, $\mathrm{L} / \mathrm{G}$ is the relative position of step, and $F_{G}$ is the Froude number under the gate.

Also the relative energy loss through the gate referring to (Fig. 1) is computed as follows:

$\mathrm{E}_{\mathrm{L}}=\mathrm{E}_{1}-\mathrm{E}_{2}$

$\mathrm{E}_{1}=\mathrm{V}^{2}{ }_{1} / 2 \mathrm{~g}+\mathrm{H}_{\mathrm{U}}$

$\mathrm{E}_{2}=\mathrm{V}^{2}{ }_{2} / 2 \mathrm{~g}+\mathrm{d}_{1}$

$\mathrm{E}_{\mathrm{L}} / \mathrm{E}_{1}=1-\left(\mathrm{E}_{2} / \mathrm{E}_{1}\right)$

Where $E_{1}$ is the energy head upstream the gate, $E_{2}$ is the energy head downstream the gate at vena-contracta, $\mathrm{E}_{\mathrm{L}}$ is the energy loss through the gate, and $\mathrm{V}_{1}, \mathrm{~V}_{2}$ are the velocities of flow at sections 1 and 2 as shown in Fig. (1).

\section{COLLECTION OF EXPERIMENTAL DATA}

The experimental work of this study was conducted using a re-circulating adjustable flume of $15.0 \mathrm{~m}$ long, $45 \mathrm{~cm}$ deep and $30 \mathrm{~cm}$ wide, Habib (2002). The discharges were measured using pre-calibrated orifice meter fixed in the feeding pipeline. The tailgate fixed at the end of the flume was used to control the tail-water-depth of flow. The radial basin was made from a clear prespex to enable visual inspection of the phenomenon being under investigation. The model length was kept constant at $130 \mathrm{~cm}$ and the angle of the divergence was kept constant to $5.28^{\circ}$ such that the expansion ratio is 1.67 . The model was fixed in the middle third of the flume between its two side-walls as seen in Fig. (1). A smooth block of wood was formed to fit well inside the basin model extending from upstream the gate by 5.0 $\mathrm{cm}$ to the position where the drop was desired. The wood was painted very well by a waterproof material (plastic) to prevent wood from changing its volume by absorbing water. Different heights of the negative step $(2.5,3.5$,
4.5, and 5.5) are used at a different position of $(0.0, .25,0.5$, and 0.75$)$ of the basin length. The range of the experimental data were as follows: Froude numbers (2.0-6.0), Z/G (0.4-2.75), L/G (0.8-25) and $\mathrm{H} / \mathrm{G}(2.9-19.5)$.

Each model was tested using five different gate openings and five discharges for each gate opening. A typical test procedure consisted of a gate opening was fixed and a selected discharge was allowed to pass then the tailgate was adjusted until a free hydraulic jump is formed. Once the stability conditions were reached, the flow rate and water depths upstream and at the vena contracta downstream of the gate were recorded. These steps were repeated for different discharges and different gate openings and so on till the required ranges of the parameters being under investigation were covered.

\section{RESULTS AND DISCUSSIONS}

\subsection{Discharge coefficient of the sluice gate}

The discharge below sluice gates is directly proportional with the discharge coefficient. So, the discharge coefficient is taken as an indicator to study the effect of the different parameters on the discharge. The case of flat bed (case of no step) is taken as a reference for the study to obtain the effect of the presence of sudden drop (negative step) on the discharge of the gate.

\subsection{1- Effect of relative height of negative step}

The variation of $\mathrm{C}_{\mathrm{d}}$ with $\mathrm{F}_{\mathrm{G}}$ for different values of relative step position $(\mathrm{L} / \mathrm{G})$ is shown in Figs. (2) and (3). It is observed that the values of $C_{d}$ decreases with the increase in $\mathrm{Z} / \mathrm{G}$ for the tested ranges of $F_{G}$ and $H / G$ for the different values of L/G. It is observed also that the presence of step reduces the values of $C_{d}$ with respect to the flat bed case. i.e. the maximum values of $C_{d}$ are attained at $\mathrm{Z} / \mathrm{G}=0.0$ (case of no step) for all the tested range of $F_{G}$ and $H / G$.

\subsection{2- Effect of relative position of negative step}

The variation of $\mathrm{C}_{\mathrm{d}}$ with $\mathrm{F}_{\mathrm{G}}$ for different values of $\mathrm{L} / \mathrm{G}$ at step relative height $(\mathrm{Z} / \mathrm{G}=0.4,0.8$, 1.0 and 2.0) is shown in Fig. (4). It is observed that the values of $\mathrm{C}_{\mathrm{d}}$ decreases with the decrease in $L / G$ then started to increase with the continuous decrease in $\mathrm{L} / \mathrm{G}$ for the tested range of $F_{G}$ for the different values of $Z / G$. It is 
observed also that the best relative position of negative step with point of view of discharge coefficient with the presence of negative step is at $\mathrm{L} / \mathrm{G}<6.0$. Fig. (5) shows this point clearly where the best positions were at $\mathrm{L} / \mathrm{G}=6.0$ and 2.0 and the smallest values of $\mathrm{C}_{\mathrm{d}}$ was at $6.0<$ $\mathrm{L} / \mathrm{G}<20$.

\subsection{Relative energy loss through the gate}

When the flow passes through the gate some of the pressure energy converted into kinetic energy i.e. the velocity of flow increases and the water depth decreases. This change in flow depth and velocity is accompanied with an energy loss. So the discharge of the gate is proportional also with the energy loss through the gate.

Fig. (6) shows the variation of $E_{L} / E_{1}$ with $C_{d}$ at different values of the parameter $\mathrm{H} / \mathrm{G}$ for the flat bed case, for different values of $\mathrm{C}_{\mathrm{d}}$. It is observed that the values of $E_{L} / E_{1}$ decrease with the increase of $C_{d}$ and increase with the increase of $H / G$ for the same $C_{d}$ value. i.e. $E_{L} / E_{1}$ is directly proportional with $\mathrm{H} / \mathrm{G}$ and inversely proportional with $\mathrm{C}_{\mathrm{d}}$.

\subsection{1- Effect of relative height of negative step}

Taking the previous result in consideration both the relation between $\mathrm{E}_{\mathrm{L}} / \mathrm{E}_{1}$ and $\mathrm{C}_{\mathrm{d}}$ w.r.t. $\mathrm{F}_{\mathrm{G}}$ is shown in Fig. (7) for different values of $L / G$ and $Z / G$. The variation of $C_{d}$ and $E_{L} / E_{1}$ with $Z / G$ for different values of step relative position $(\mathrm{L} / \mathrm{G})$ is shown in Figs. $(7 \mathrm{a}, \mathrm{b}, \mathrm{c})$. It is observed that the values of $C_{d}$ decreases while $E_{L} / E_{1}$ increases with the increase in $\mathrm{Z} / \mathrm{G}$ value for the tested range of $F_{G}$ at the different values of $\mathrm{L} / \mathrm{G}$. It is observed also that the presence of step reduces the values of $\mathrm{C}_{\mathrm{d}}$ as previously mentioned and increases the relative energy lost through the gate with respect to the flat bed case (without step). I.e. the maximum values of $\mathrm{C}_{\mathrm{d}}$ and the minimum values of $E_{L} / E_{1}$ are attained at $Z / G=$ 0.0 for all the tested range of $F_{G}$.

\subsection{2- Effect of relative position of negative step}

The variation of $E_{\mathrm{L}} / \mathrm{E}_{1}$ with $\mathrm{F}_{\mathrm{G}}$ for different values of $\mathrm{L} / \mathrm{G}$ at step relative height $(\mathrm{Z} / \mathrm{G}=0.4$, $0.8,1.0$ and 1.5) is shown in Fig. 8. It is observed that the values of $E_{L} / E_{1}$ increases with the increase in $\mathrm{L} / \mathrm{G}$ then started to decrease with the continuous increase in $\mathrm{L} / \mathrm{G}$ for the tested range of $F_{G}$ for the different values of $Z / G$. It is observed also that the maximum energy loss occurs at $10<\mathrm{L} / \mathrm{G}<20$ and the minimum energy loss at $L / G<6$ as shown clearly in Fig. 9.

\section{PREDICTION OF $C_{D}$}

Nonlinear and linear multiple regression analysis were used to analyze the experimental data. Many trials were made with different variables to obtain the best agreement between the experimental and the predicted values of $\mathrm{C}_{\mathrm{d}}$. The results of the best prediction trials are presented in table (1). Also the predicted values are plotted against the experimental values and the residuals are plotted versus the predicted values as shown in Figs. $(10-13)$. The results of the models showed good agreement between the experimental and predicted values of $C_{d}\left(R^{2}\right.$ $=0.99$ for all models) and $\mathrm{R}^{2}$ between residuals and predicted values are $(0.009,0.004,0.007$ and 0.01 ) respectively.

It is observed also from the results of the different trials that the values of $\mathrm{Z} / \mathrm{G}$ and $\mathrm{L} / \mathrm{G}$ have a small effect on the discharge coefficient compared to the other variables. And the increase in relative energy loss decreases the corresponding discharge coefficient. 
Table (1) : Predicted Models of $\mathbf{C}_{\mathbf{d}}$

\begin{tabular}{|c|c|}
\hline $\begin{aligned} & \text { Model 1 }\left(\mathbf{R}^{2}=\mathbf{0 . 9 9 6}\right) \\
\mathrm{C}_{\mathrm{d}}= & -0.391 \mathrm{E}_{\mathrm{L}} / \mathrm{E}_{1} \\
& +6.457 \mathrm{E}-04 \mathrm{~d}_{2} / \mathrm{G} \\
& +0.464 \mathrm{~F}_{\mathrm{G}}^{2} \\
& -0.928 \mathrm{H} / \mathrm{G} \\
& -2.539 \mathrm{E}-04 \mathrm{Z} / \mathrm{G} \\
& +7.150 \mathrm{E}-06 \mathrm{~L} / \mathrm{G} \\
& +0.974\end{aligned}$ & $\begin{aligned} & \underline{\text { Model 2 }\left(\mathbf{R}^{2}=\mathbf{0 . 9 9 6}\right)} \\
\mathrm{C}_{\mathrm{d}}=\exp \left(-0.391 \mathrm{E}_{\mathrm{L}} / \mathrm{E}_{1}\right. & +6.458 \mathrm{E}-04 \mathrm{~d}_{2} / \mathrm{G} \\
& +0.464 \mathrm{~F}_{\mathrm{G}}{ }^{2} \\
& -0.928 \mathrm{H} / \mathrm{G} \\
& -2.539 \mathrm{E}-04 \mathrm{Z} / \mathrm{G} \\
& +7.150 \mathrm{E}-06 \mathrm{~L} / \mathrm{G} \\
& +0.974)\end{aligned}$ \\
\hline $\begin{aligned} & \text { Model 3 }\left(\mathbf{R}^{2}=\mathbf{0 . 9 9 6}\right) \\
\mathrm{C}_{\mathrm{d}}=- & 0.391 \mathrm{E}_{\mathrm{L}} / \mathrm{E}_{1} \\
& +0.463 \mathrm{~F}_{\mathrm{G}}^{2} \\
& -0.926 \mathrm{H} / \mathrm{G} \\
& -2.017 \mathrm{E}-04 \mathrm{Z} / \mathrm{G} \\
& +2.237 \mathrm{E}-06 \mathrm{~L} / \mathrm{G} \\
& +0.974\end{aligned}$ & $\begin{aligned} \mathrm{C}_{\mathrm{d}}=\exp (- & \text { Model 4 }\left(\mathbf{R}^{2}=\mathbf{0 . 9 9 4}\right) \\
& +064 \mathrm{E}_{\mathrm{L}} / \mathrm{E}_{1} \\
& -0.784 \mathrm{~F}_{\mathrm{G}}{ }^{2} \\
& -6.567 \mathrm{H} / \mathrm{G} \\
& +1.435 \mathrm{E}-04 \mathrm{E}-056 \mathrm{G} / \mathrm{G} \\
& +0.123)\end{aligned}$ \\
\hline
\end{tabular}
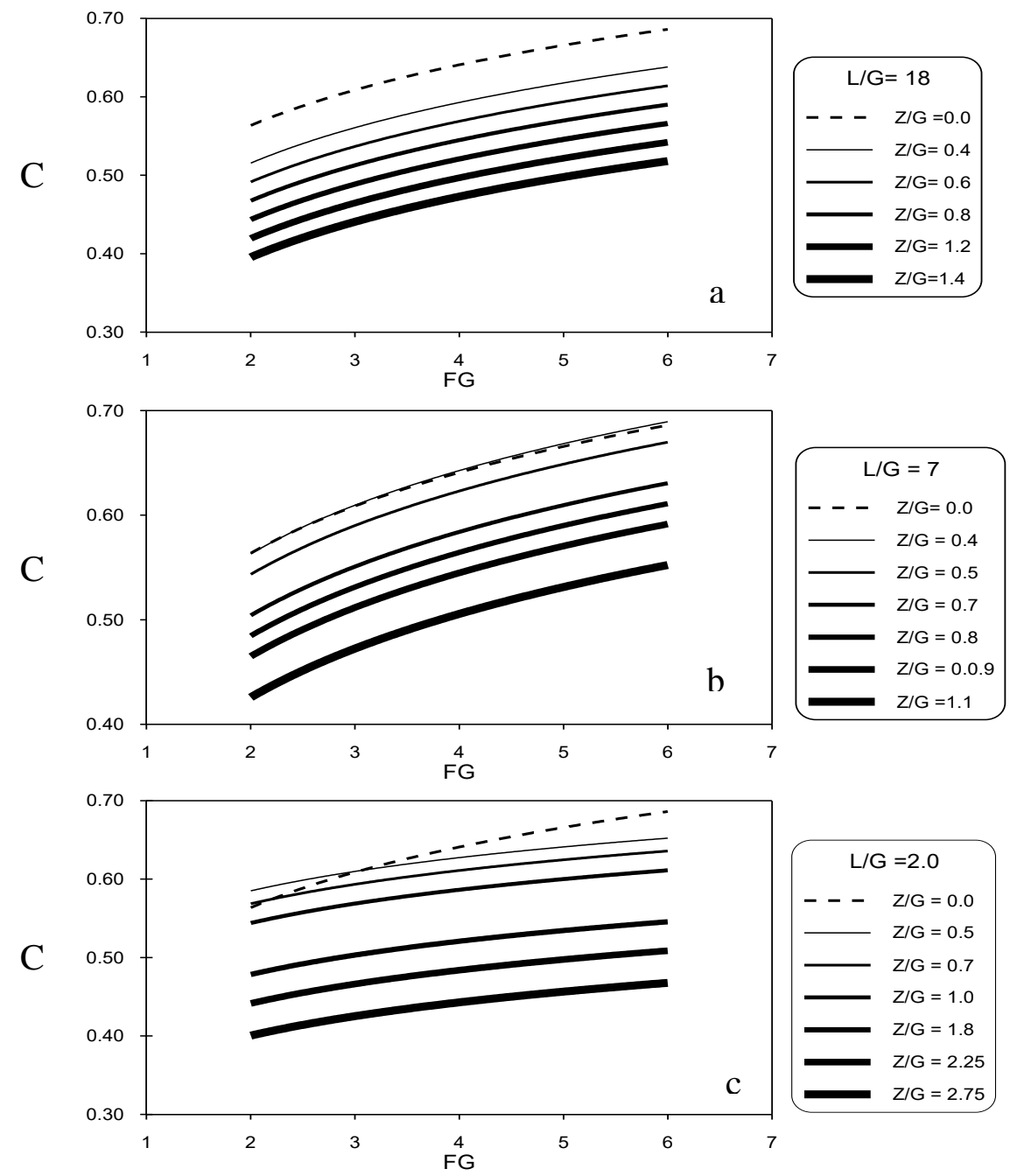

Fig. (2): Variation of $C_{d}$ with $F_{G}$ for different values of $Z / G$ at a) $L / G=18, b) L / G=7.0$ and $c) L / G=2.0$ 
Characteristics of Free flow Below Sluice Gate Below Radial Stilling Basin with Negative Step
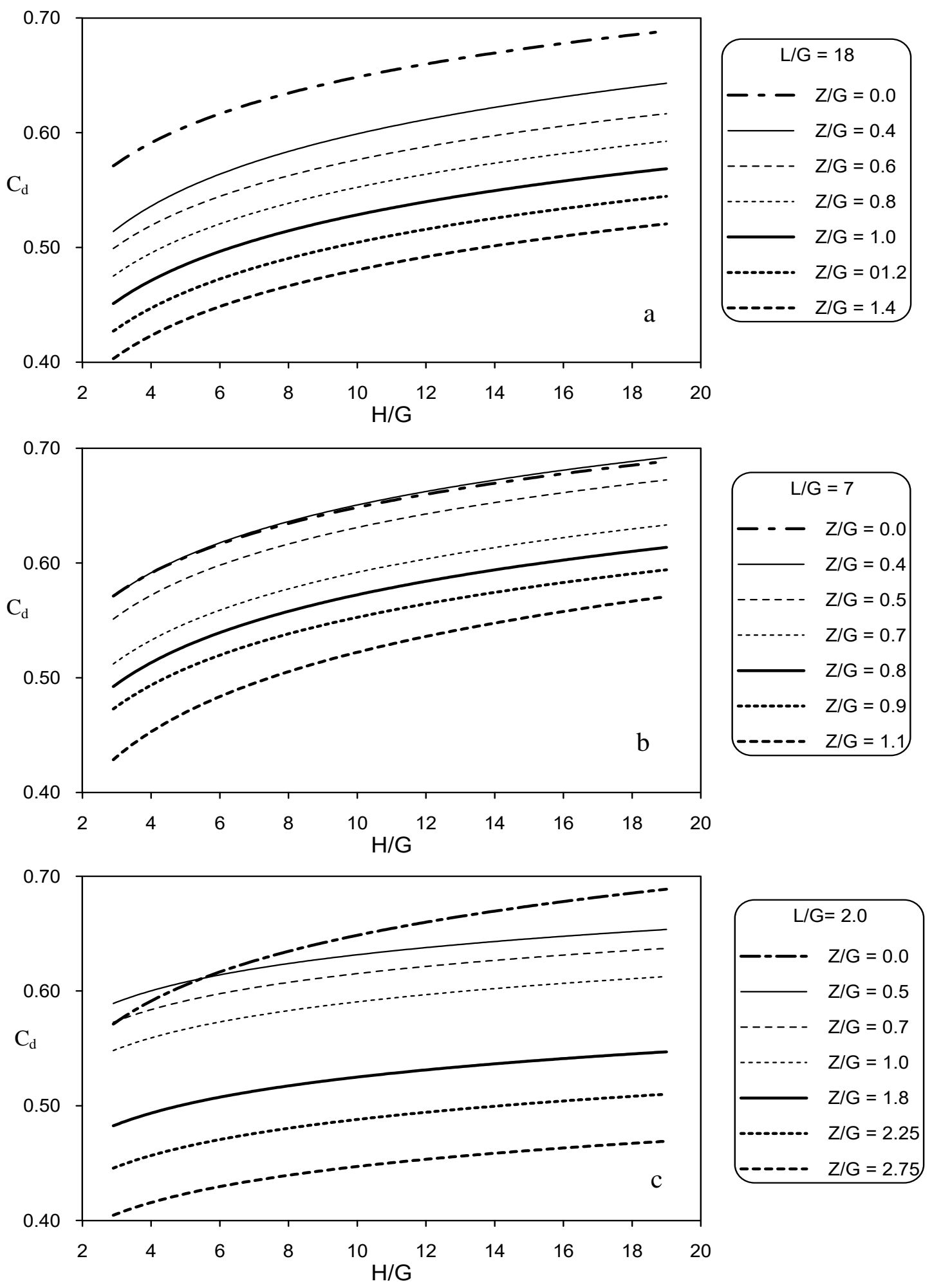

Fig. (3): Variation of $C_{d}$ with $H / G$ for different values of $Z / G$ at a) $L / G=18$, b)

$$
L / G=7.0 \text { and } c) L / G=2.0
$$




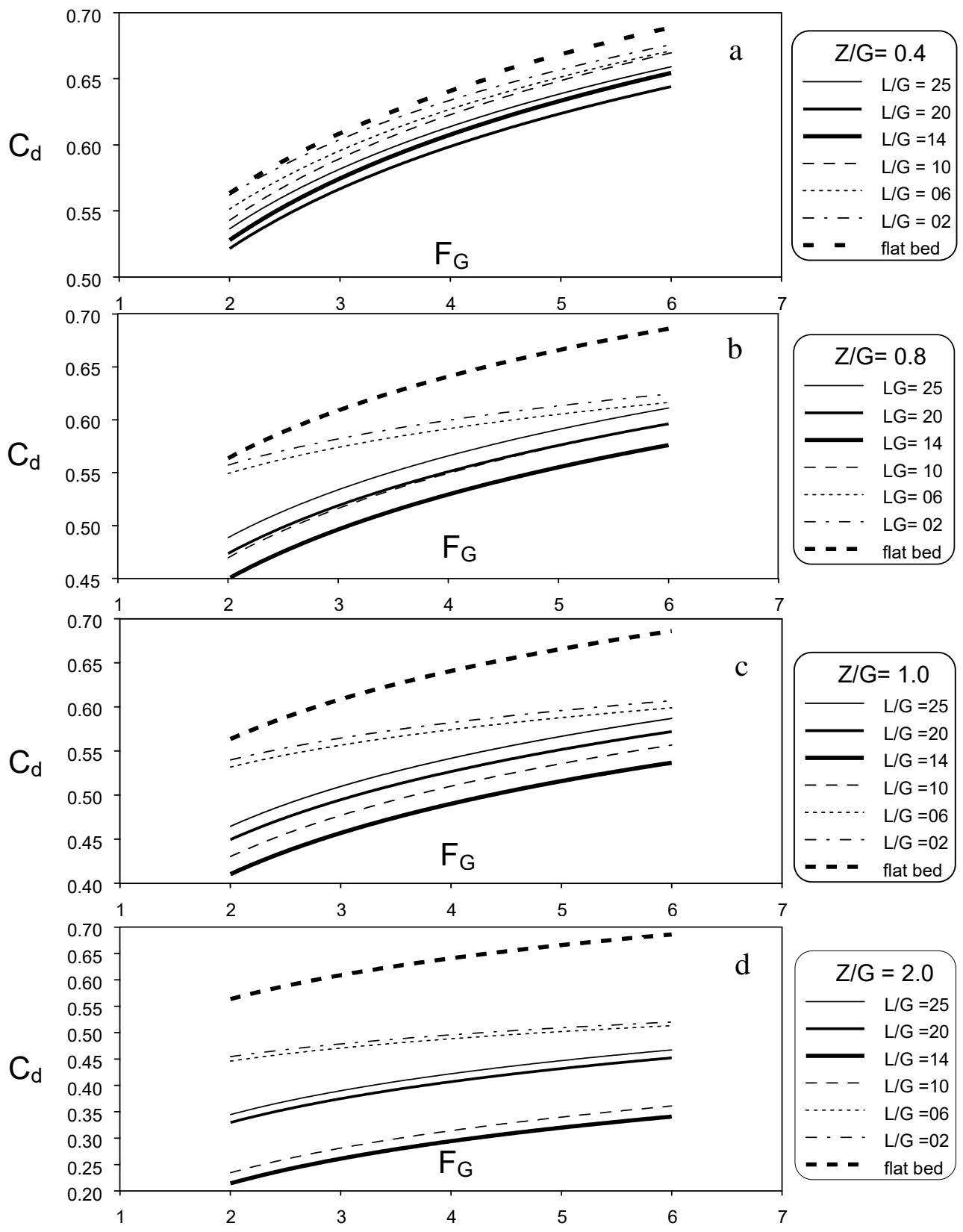

Fig. (4): Variation of $C_{d}$ with $F_{G}$ for different values of $L / G$ at a) $Z / G$ $=0.4, \mathrm{~b}) \mathrm{Z} / \mathrm{G}=\mathbf{0 . 8}, \mathrm{c}) \mathrm{Z} / \mathrm{G}=\mathbf{1 . 0}$ and d) $\mathrm{Z} / \mathrm{G}=\mathbf{2 . 0}$

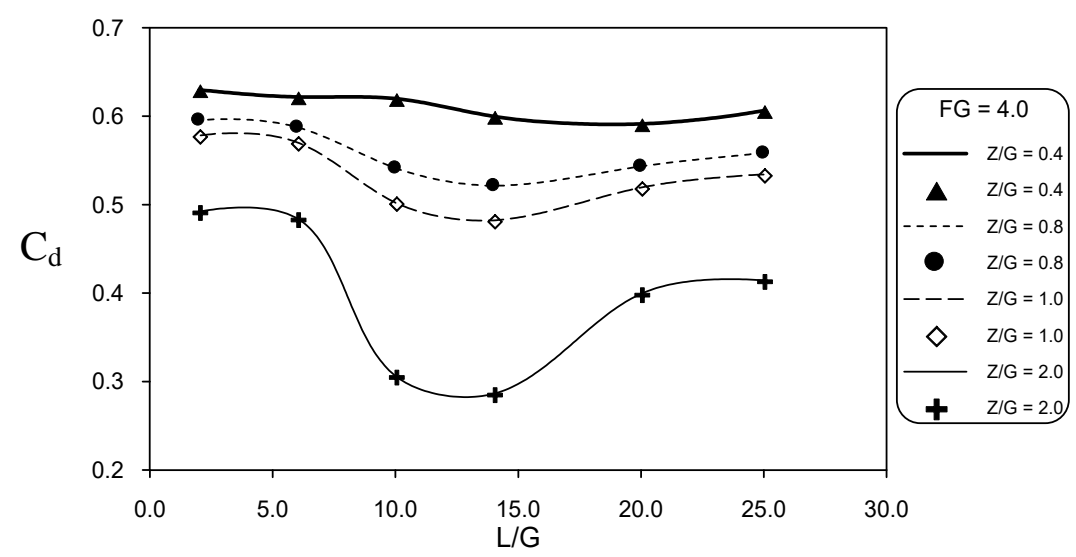

Fig. (5): Relation between $C_{d}$ and $L / G$ for $F_{G}=4.0$ 
Characteristics of Free flow Below Sluice Gate Below Radial Stilling Basin with Negative Step

Habib

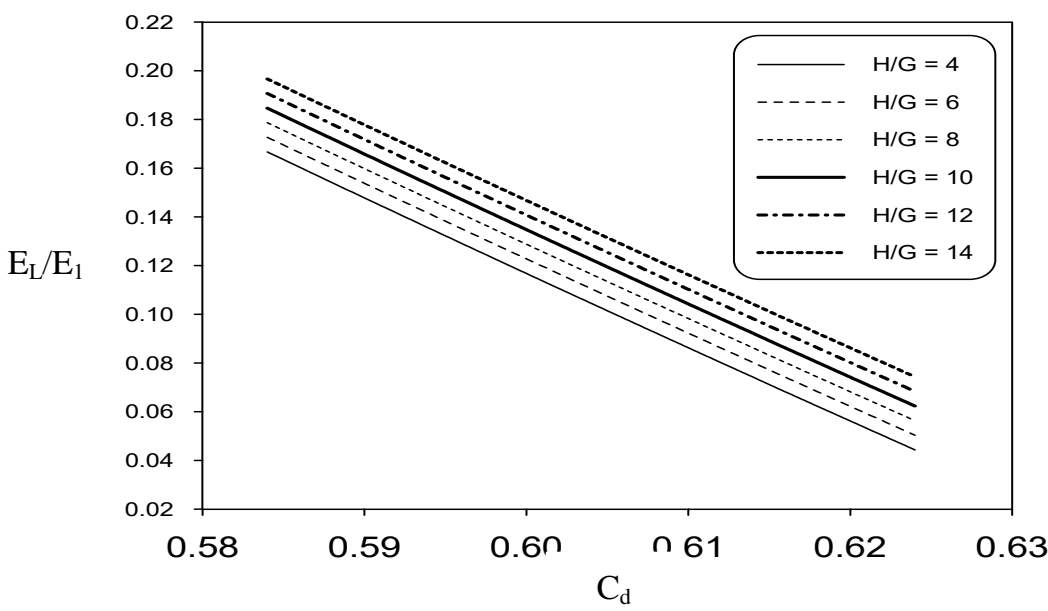

Fig. (6): Relation between $E_{L} / E_{1}$ and $C_{d}$ for different values of $H / G$ (Flat Bed Case)
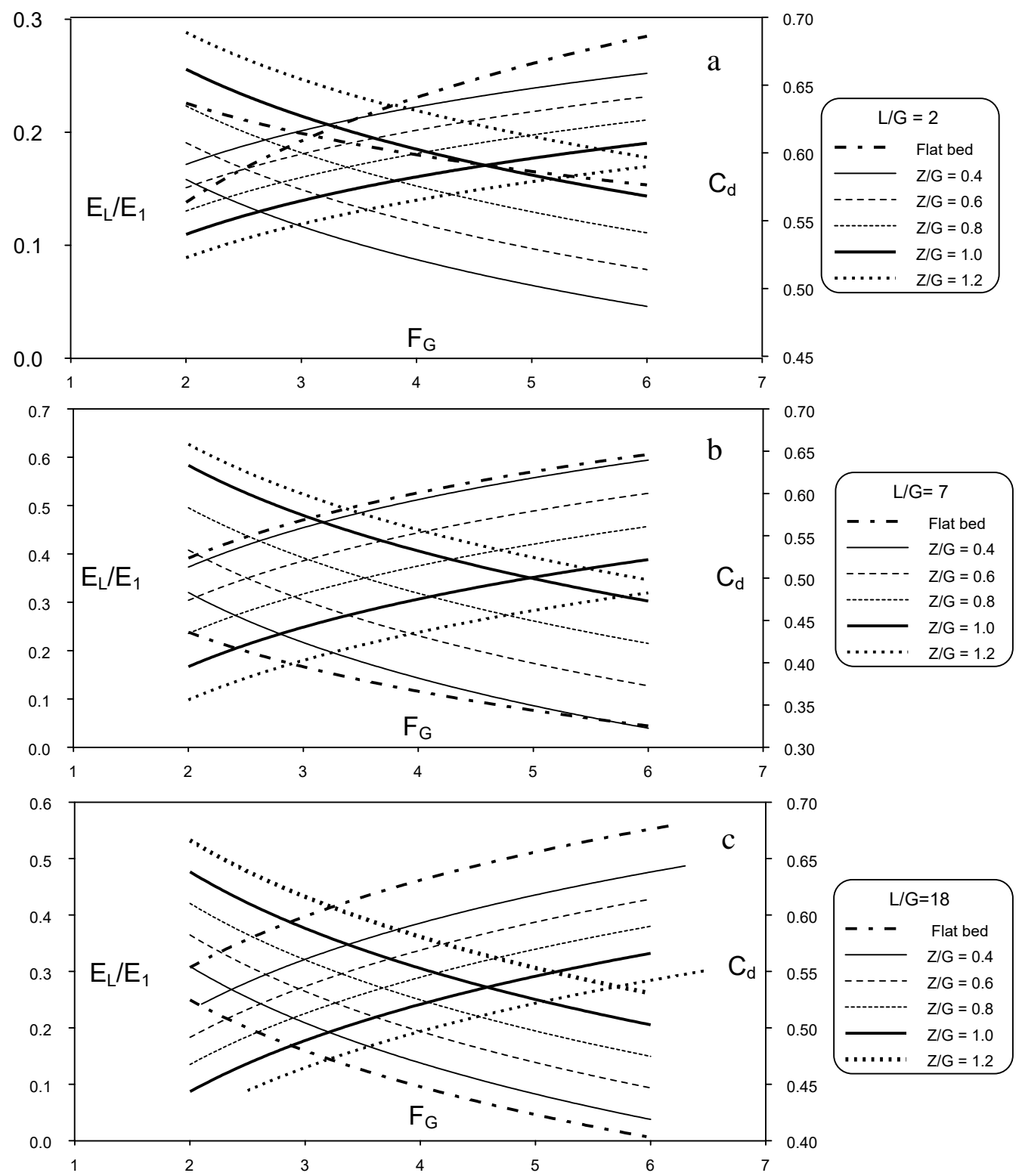

Fig. (7): Variation of both $E_{L} / E_{1}$ and $C_{d}$ with $F_{G}$ for different values of $Z / G$ at a) $L / G=2, b) L / G=7$ and c) $L / G=18$ 

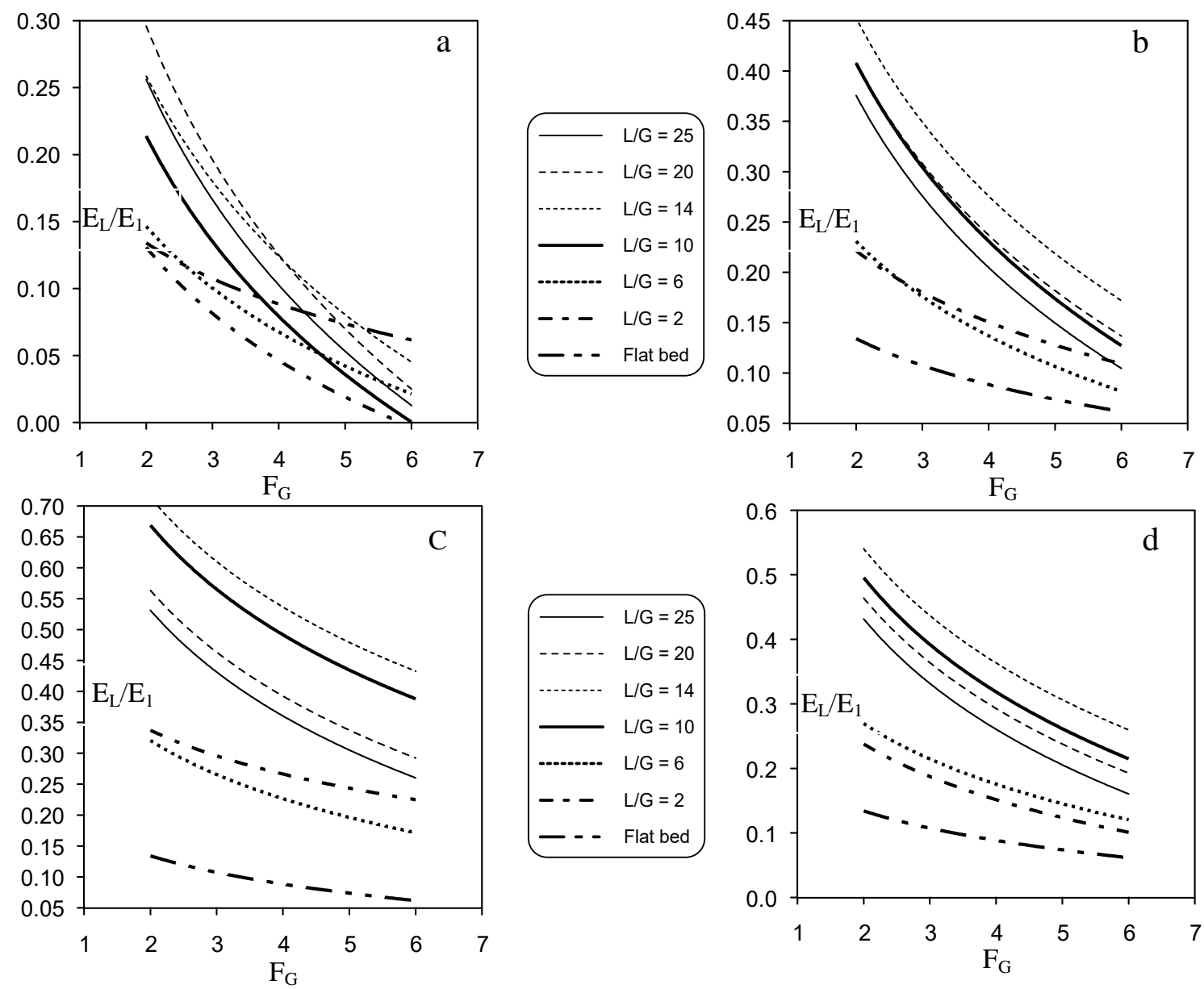

Fig. (8): Variation of $E_{L} / E_{1}$ with $F_{G}$ for different values of $L / G$ at a) $Z / G=0.4$, b) $\mathrm{Z} / \mathrm{G}=0.80, \mathrm{c}) \mathrm{Z} / \mathrm{G}=1.0$ and d) $\mathrm{Z} / \mathrm{G}=\mathbf{1 . 5}$

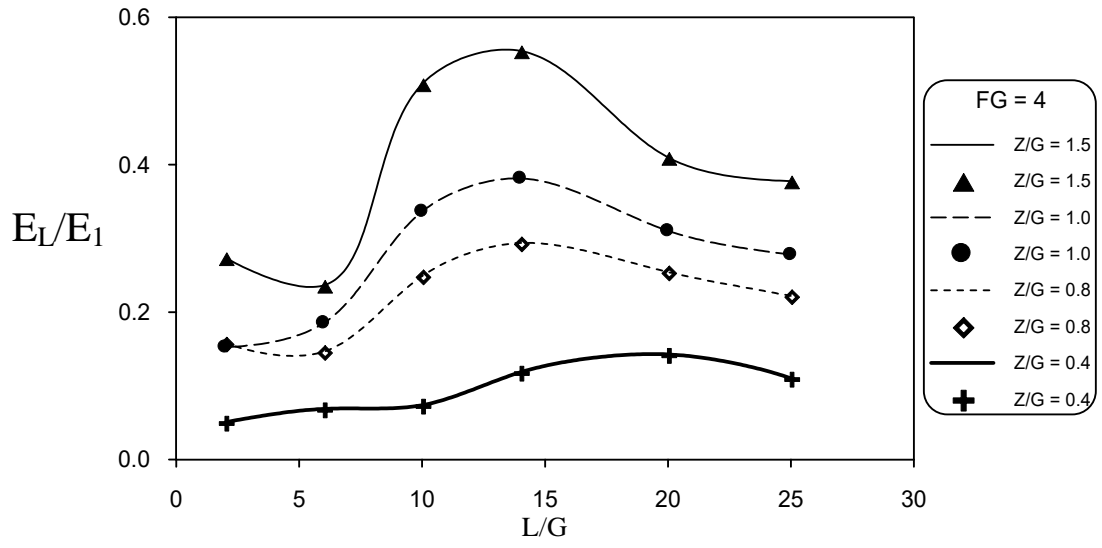

Fig. (9): Relation between $E_{L} / E_{1}$ and $L / G$ for $F_{G}=4.0$ 

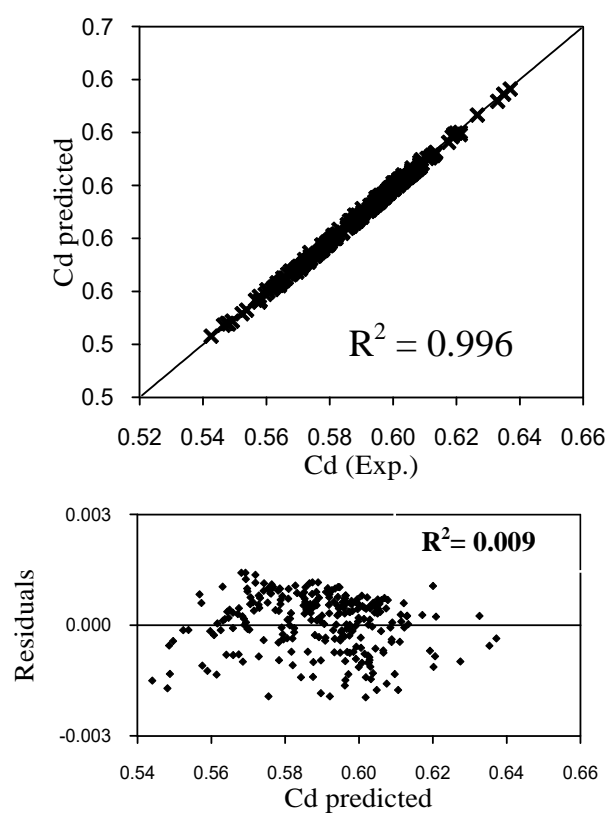

Fig. (10): Results of model (1)
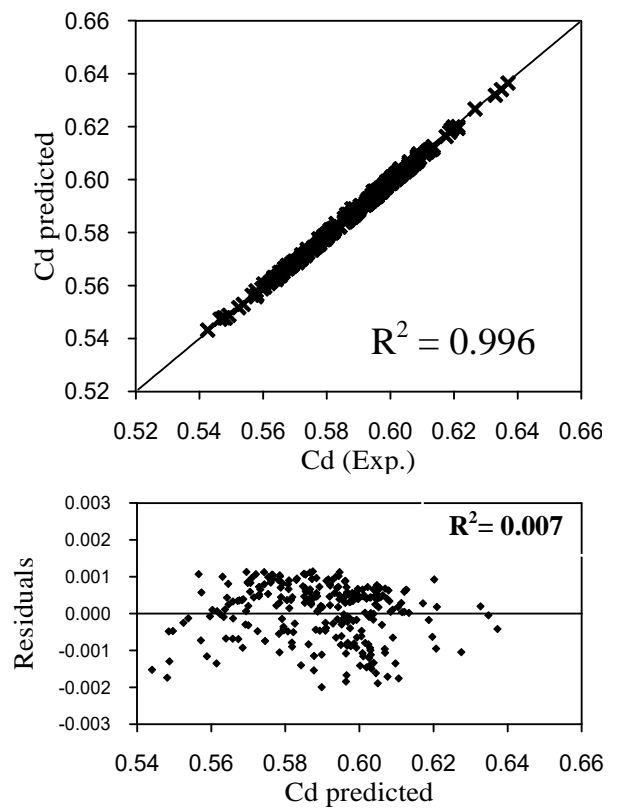

Fig. (12): Results of model (3)

\section{CONCLUSIONS}

An experimental investigation is conducted in a laboratory flume using negative steps of different heights and positions in a radial stilling basin to investigate the effects of the step relative heights and relative positions on the discharge coefficient and the energy loss
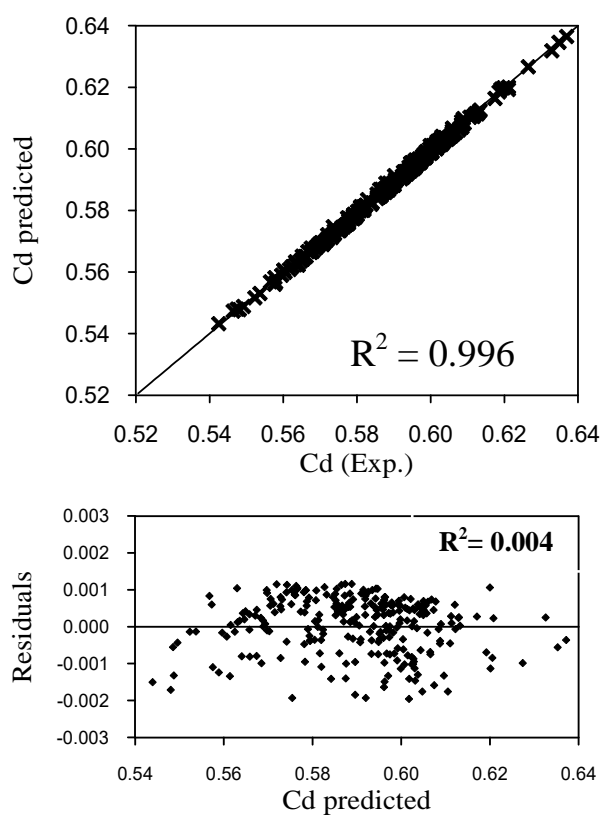

Fig. (11): Results of model (2)
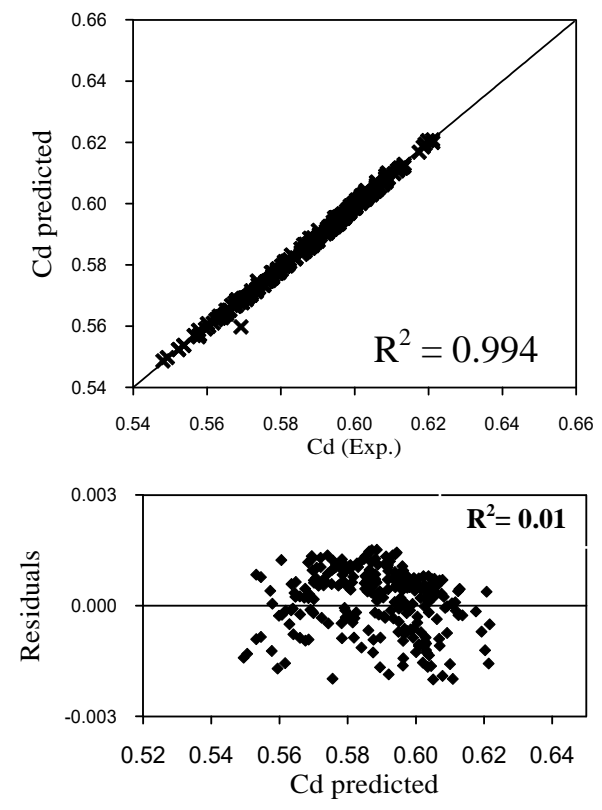

Fig. (13): Results of model (4)

through the free sluice gate upstream the basin. The results indicated that:

- The values of $C_{d}$ decrease with the increase in $Z / G$ for the tested ranges of $F_{G}$ and $\mathrm{H} / \mathrm{G}$ for the different values of $\mathrm{L} / \mathrm{G}$ and the presence of step reduce the values of $C_{d}$ with respect to the flat bed case. So the maximum values of $\mathrm{C}_{\mathrm{d}}$ can be attained at $\mathrm{Z} / \mathrm{G}=0.0$. 
- The best relative positions of negative step with point of view of discharge coefficient with the presence of negative step are at $\mathrm{L} / \mathrm{G}$ $<6.0$.

-The smallest values of $\mathrm{C}_{\mathrm{d}}$ are at the range $6.0<\mathrm{L} / \mathrm{G}<20$.

- The relative energy loss through the gate $\mathrm{E}_{\mathrm{L}} / \mathrm{E}_{1}$ is directly proportional with $\mathrm{H} / \mathrm{G}$ and $F_{G}$ and is inversely proportional with $C_{d}$, i.e $E_{L} / E_{1}$ increases with the increase in $H / G$ and with the decrease in $\mathrm{C}_{\mathrm{d}}$.

- The values of $E_{L} / E_{1}$ increase with the increase in $\mathrm{Z} / \mathrm{G}$ for the tested range of $\mathrm{F}_{\mathrm{G}}$ for the different values of $\mathrm{L} / \mathrm{G}$. The presence of step increases the relative energy loss through the gate compared to the flat bed case, i.e. the minimum values of $\mathrm{E}_{\mathrm{L}} / \mathrm{E}_{1}$ are attained at $\mathrm{Z} / \mathrm{G}=0.0$ for all the tested range of $\mathrm{F}_{\mathrm{G}}$.

- The values of $E_{L} / E_{1}$ increase with the increase in $L / G$ then started to decrease with the continuous increase in $L / G$ for the different values of $Z / G$.

- The discharge coefficient increases with the decrease in the relative energy loss.

- The values of $Z / G$ and $L / G$ have a small effect on the discharge coefficient compared to the other variables.

\section{Notation}

$\mathrm{b}:$ Width of the flume at the gate location $(18 \mathrm{~cm})$

B : Width of the flume at the end of the basin $(30 \mathrm{~cm})$

$\mathrm{C}_{\mathrm{d}}$ : Coefficient of discharge of free sluice gate

$\mathrm{E}_{1}$ : Energy head upstream the gate

$\mathrm{E}_{2}$ : Energy head downstream the gate at vena-contracta

$\mathrm{E}_{\mathrm{L}}$ : Energy lost through the gate

$\mathrm{E}_{\mathrm{L}} / \mathrm{E}_{1}$ : Relative energy loss through the gate

$\mathrm{d}_{1}$ : initial water depth of free hydraulic jump D.S. the gate

$\mathrm{d}_{2}$ : Tail water depth.

$\mathrm{F}_{\mathrm{G}}$ : Froude number under gate

$\mathrm{G}$ : Gate opening height

$\mathrm{g}$ : Acceleration due to gravity

$\mathrm{H}$ : Upstream water depth over venacontracta

$\mathrm{H}_{\mathrm{U}}$ : Upstream water depth over the bed.

$\mathrm{L}$ : Position of step downstream the gate

$\mathrm{L}_{\mathrm{b}}$ : Radial basin length $(130 \mathrm{~cm})$
- The maximum energy loss occurs at $10<$ $\mathrm{L} / \mathrm{G}<20$ and the minimum energy loss at $\mathrm{L} / \mathrm{G}<6$.

Four dimensionless models in terms of the flow and step parameters for computing the coefficient of discharge of the sluice gate are developed using the multiple regression analysis. The obtained predictions of the discharge coefficient using the developed equations are compared to the experimental data. And the results of the comparison indicted that:

- The models 1, 3 of linear form and 2, 4 of exponential form proved good reliability and high accuracy where the correlation coefficient between the experimental and the predicted values are $\left(R^{2}=0.99\right)$ for all models.

- There is a high reliability between $C_{d}$ and $\mathrm{E}_{\mathrm{L}} / \mathrm{E}_{1}$.

Q : Discharge passing through the flume

$\mathrm{Z}$ : Depth of negative vertical step

$\theta$ : Angle of divergence of the basin

\section{REFERENCES}

1) Abdelaal, G.M.M., (1990), "Study of the Free Flow Conditions for Silled Gates", Unpublished M.Sc. Thesis, Faculty of Engineering, Ain Shams University, Cairo, Egypt.

2) Abdel-Aal, G.M., (1999),"Study of Hydraulic Jump in Gradually Expanding Rectangular Channels", Scientific Bulletin, Faculty of Engineering, Ain Shams University, Vol. 34, No. 4, pp. 339-351.

3) Abdel-Aal, G.M., (2000),"A Study of Stilling Basins in Non-PrismaticChannels", Scientific Bulletin, Faculty of Engineering, Ain Shams University, Vol. 35, No. 1, pp. 207-222.

4) Arbhabhirama, A. and Abella, A.U., (1972), "Hydraulic Jump within Gradually Expanding Channel", Journal of the Hydraulic Division, Vol. 97, No. HY1, Jan., pp. 31-41.

5) El-Saiad, A., (1990), "Study of Submerged Flow Characteristics Under Silled Sluice Gates", Unpublished M.Sc. Thesis Ain Shams University, Cairo, Egypt. 
6) El-Saiad, Atef A., Abdel Hafiz, Essam and Hammad, M. N., (1991), "Effect of Sill under gate on the discharge Coefficient"J. The Egyptian Society of Engineers, Vol.30, No.2, pp. 13-16.

7) France, P.W., (1981), "Analysis of the Hydraulic Jump within a Diverging Rectangular Channel", Proc. Instn., Civil Engineering, Part 2, June, 71, pp. 369-378.

8) Habib, A.A., (2002), "Characteristics of Flow in Diverging Stilling Basins", Unpublised PH. D., Faculty of Engineering, Zagazig University.

9) Henderson, F.M., (1966), "Open Channel Flow" , New York, Maemllan Publishing Co. Inc..

10) Henery, H., (1950), " Diffusion of Submerged Jets " Trans. Proc. ASCE, 115, pp. 687-697.

11) Ibrahim, A.A., (2000), "Analysis and Formulation of Supercritical Submerged Flow Below Gate in Radial Basin With Lateral Sill", Engineering Research Journal, Al-Mataria Faculty of Eng., HelwanUniversity, Vol. 68, April, pp. 117130.

12) Khalifa, Abdelkawi M.,and Mcorquodale J.A., (1979), "Radial Hydraulic Jump", Journal of the Hydraulic Division, ASCE., Vol. 105, No. HY9, Proc. Paper 14825, September, pp. 1065-1078.

13) Negm, A.M., Abouelatta, N. and Abdellateef, M., (1993), "Supercritical Free Flow Characteristics under Silled Sluice Gate", Scientific Bulletin, Faculty of Engineering, Ain Shams University, Cairo, Egypt, pp.163-174.

14) Negm, A. M.; Abdellateef, M. and Owais, T. M., (1993) "Effect of Under-Ggate Sill Crest Shapes on the Flow Characteristics", Proc. of AEIC-93, 18-21 Dec., Faculty of Eng., Al-Azhar University, Naser City, Cairo, Egypt, Vol.4, pp. 230-241.

15) Negm, A. M. and El-Saiad, A. A., (1993), "Subcritical Submerged Flow Characteristics Beneath Silled Sluice Gates" Proc. of AEIC-93, December 18-21, Faculty of Engineering, Al-Azhar University, Naser City, Cairo, Egypt, vol.4, pp. 298-309.

16) Negm, A.M., (1994), "Optimum Relative Height of the Optimal Under-Gate Sill for Ssupercritical Submerged Flow Below Sluice Gates",19th Int. Conf. for Statistic, Computer Science, Scientific and Social
Applications, 9-14 April, Engineering Science, Cairo, Egypt, Vol.1, pp. 39-49.

17) Negm, A.M., Abdelaal, G. M., Owais, T. M., Abdellateef, M. and Hammad, M.N., (1995), "Characteristics of Free Hydraulic Jump Downstream Silled Sluice Gates",J. Water and Energy International, CBIP, India, pp.45-51.

18) Negm, A.M., Abdel-Aal, G.M., El-Saiad, A.A. and Ibrahim, A.A., (2000a), "Characteristics Of Free Flow Below Gates In Sloping RadialStilling Basin", Proceeding of Al-Mansoura 3rd Int. Engineering Conference, April 11-13, Faculty of Engineering, ElMansouraUniversity, El-Mansoura, Egypt, Vol. 1, pp. 343-357.

19) Negm, A.M., Abdel-Aal, G.M., Ibrahim, A.A., and El-Saiad, A.A., (2000b), "Discharge Equation For Free Flow Below Gates Us Of Sloping Diverging Channel Reach", Egyptian Journal for Engineering Science and Technology (EJEST), Faculty of Engineering, Zagazig University, Zagazig, Egypt, Vol. 4, April, pp. 69-80.

20) Ohatsu, I. and Yasuda, Y., (1994) "Characteristics of Subcritical Flow Below Sluice Gate" Journal of Hydraulic Engineering, ASCE, 120, No. 3, pp. 332346.

21) Rajratnam, N. and Subramanya. K., (1967), "Flow Equation for Sluice Gate" Journal of Irrigation and Drainage Division, ASCE, 93, No.4, pp. 167-186.

22) Rajratnam, N., (1997), "Free flow Immediately Below Sluice Gate." Journal of hydraulics division, ASCE, 102, No 4, pp. 345-351.

23) Ranja Raju, K.G. and Visavadia, D. S., (1979), "Discharge Characteristics of a Sluice Gate Located on a Raised Crest", Proc. IMEKO in Industry Tokyo, Japan, Nov., pp. 39-43.

24) Ranja Raju, K.G., (1981), "Flow Through Open Channels", Tata McGraw Hill Publishing Company Limited, pp.246-247.

25) Swamee, P.K., (1992), "Sluice-Gate Discharge Equations" Journal of Irrigation and Drainage Engineering, Proc. ASCE, 118, No. 1, pp. 57-60. 